\title{
Effects of Superplasticizer on the Properties of Fresh and Hardened Concrete Mixes
}

\author{
Randa Muddather ${ }^{1, *}$ and A. E. Hassaballa ${ }^{2}$ \\ 1 Civil Engineering Department, University of Gezira, Sudan \\ 2 Department of Civil Engineering, Jazan University, Jazan, KSA. \\ * Corresponding author: Randa Muddather (e-mail: randa2016mud@gmail.com).
}

Article history: Received 02 April 2020, Received in revised form 4 November 2020, Accepted 11 November 2020

\begin{abstract}
This research aims to study the effect of superplasticizer, when mixed with local materials, on both fresh and hardened concrete properties to achieve the demands of engineers and contractors. The methodology adopted to achieve the objectives of the research focuses mainly on a collection of data from different sources, an extensive review of previous studies, designing concrete mixes and implementing a lot of laboratory experiments using different ratios of superplasticizer with low water contents. The ratios of superplasticizer added were 0.0 (as a reference mix), $0.4,0.8,1.2$ and 1.5 Litre/ $50 \mathrm{Kg}$ cement for concrete ages of 3, 7 and 28 days by preparing 12 cubes for each sample. Local ordinary Portland cement (OPC) and graded natural coarse and fine aggregate were used for all concrete mixes conducted in this research. From the experimental results obtained it has been found that the ratio of ( 0.8 litres per $50 \mathrm{~kg}$ of cement) superplasticizers with a reduction of $15 \%(\mathrm{w} / \mathrm{c})$ showed a clear and significant effect on improving the workability of concrete mixes. Also the ratios of 1.5L per $50 \mathrm{~kg}$ of cement with a $30 \%$ reduction of $(\mathrm{w} / \mathrm{c}$ (and $0.4 \mathrm{~L}$ per $50 \mathrm{~kg}$ of cement with a reduction of $10 \%$ )w/c) superplasticizer have resulted in high workability. Whereas, the values of absorption showed no changes with respected to the used ratios of SP or w/c contents. The results have shown substantial improvement in the properties of concrete after use of the superplasticizers for achieving the lowest possible water/cement ratio while maintaining a high workability.
\end{abstract}

Keywords: Superplasticizer; Workability; Absorption; Concrete Mixes; (W/C) Ratio.

\section{INTRODUCTION}

Concrete is a composite product produced by mixing cement, aggregates and water and sometimes admixture if needed, undergoes a number of operations such as handling, placing and curing. Inspection and control at all stages of procurement of raw materials to the development of finish product contributes to the uniformity of concrete.

Concrete has occupied an important place among construction materials and is widely used in all types of civil engineering structures ranging from a small building to heavy structures, ever since concrete has been accepted as a material [1].

Concrete consists of four ingredients which can be classified in to two groups: Active group and inactive group. The active group consists of water and cement, while the inactive group consists of fine and coarse aggregates [2].

Superplasticizers are sometimes described as high range water reducers. The first generation of superplasticizers were commercially launched in the early 1960's and had an effective working life of less than one hour, the current generation of superplasticizers can be effective for periods of up to four hours [3]. Superplasticizers were first used in the United Kingdom in 1973. The original application of superplasticizers was for the production of flowing concrete, they now have far wider applications including the production of high strength and/or early drying screed mixes. When used as water reducer typical water reductions compared to a control mix can be in the order of $30 \%$. Superplasticizers can be used in the same three ways as a conventional plasticizer: 
- To impart extreme workability (beyond that obtainable with a conventional plasticizer).

- To permit a large water reduction to be made beyond the limits of normal plasticizing admixtures.

- To achieve economic and environmental benefits (e.g. reduction of the cement content) whilst maintaining performance.

The materials used to manufacture superplasticizers include:

- Melamine formaldehyde condensates(introduced in Germany in 1964)

- Naphthalene Formaldehyde (introduced in Japan 1963)

- Modified lignosulfonate

- Synthetic polymers

These admixtures can enormously increase the workability of normal Portland cement concrete or greatly reduce its water content. The dosage requirements vary between 0.5 and 3 percent by weight of cement, depending on the type of admixture used.

Normally the superplasticizer is added to the truck mixer after it arrives at the jobsite and at the last convenient moment before discharge. Within 5 minutes or less the slump greatly increases and at this time the user can get the most advantage from the high fluidity of the concrete [5].

\section{MATERIALS AND METHOD}

\subsection{Introduction}

In this research, an intensive laboratory tests to investigate the effect of superplasticizer on the properties of workability and water absorption of concrete mixes has been conducted. Preliminary tests for local ordinary Portland cement and

Table (2): Results of sieve analysis of coarse aggregate test

\begin{tabular}{|c|c|c|c|c|c|c|c|}
\hline \multirow{3}{*}{$\begin{array}{l}\text { B.S } \\
\text { seive } \\
(\mathrm{mm} \\
)\end{array}$} & \multicolumn{5}{|c|}{ Retained } & \multirow{3}{*}{$\begin{array}{c}\text { \%age } \\
\text { Passin } \\
\text { g }\end{array}$} & \multirow[t]{3}{*}{ BS } \\
\hline & \multicolumn{2}{|c|}{ Sample (1) } & \multicolumn{2}{|c|}{ Sample (2) } & \multirow{2}{*}{$\frac{\text { Average }}{(\%)}$} & & \\
\hline & Wt. (g) & $(\%)$ & Wt. (g) & $(\%)$ & & & \\
\hline 25 & 0 & 0 & 0 & 0 & 0 & 100 & 100 \\
\hline 19.5 & 0.129 & 6.45 & 0.131 & 6.55 & 6.5 & 93.5 & $\begin{array}{l}85 \text { to } \\
100\end{array}$ \\
\hline 12.5 & 1.113 & 55.6 & 1.265 & 63.25 & 59.425 & $\begin{array}{c}34.07 \\
5\end{array}$ & 0 to 70 \\
\hline 9.5 & 0.567 & 28.35 & 0.450 & 22.5 & 25.425 & 8.65 & 0 to 25 \\
\hline 4.75 & 0.185 & 9.25 & 0.155 & 7.75 & 8.5 & 0.15 & 0 to 5 \\
\hline pan & 0.006 & 0.3 & 0.0 & 0 & 0.15 & 0 & \\
\hline
\end{tabular}

aggregate used in the research have been carried out. The ratios of superplasticizer added were 0.0 (as a reference mix), 0.4, 0.8, 1.2 and 1.5 Litre/ 50

$\mathrm{Kg}$ cement for concrete ages of 3, 7 and 28 days by TABle (1): Results of Preliminary Cement Tests

\begin{tabular}{|c|c|c|}
\hline Test & Results & $\begin{array}{c}\text { Requirements of BS } 12 \\
1996\end{array}$ \\
\hline Consistency & $29.0 \%$ & $26-32 \%$ \\
\hline \multicolumn{3}{|l|}{ Setting Time } \\
\hline a) Initial & $2 \mathrm{hrs}$ & $\begin{array}{c}\text { Not less than } 60 \min (-15 \\
\min )\end{array}$ \\
\hline b) Final & $\begin{array}{c}3 \text { hrs: } 10 \\
\min \end{array}$ & Not more than 10 hrs. \\
\hline $\begin{array}{c}\text { Compressive } \\
\text { Strength }\end{array}$ & & \\
\hline a) 2 days & & $\begin{array}{l}\text { Equal or Greater than } 10 \\
\mathrm{~N} / \mathrm{mm} 2\end{array}$ \\
\hline 1 & $\begin{array}{c}17.6 \\
\mathrm{~N} / \mathrm{mm}^{2} \\
\end{array}$ & \\
\hline 2 & $\begin{array}{c}17.2 \\
\mathrm{~N} / \mathrm{mm}^{2} \\
\end{array}$ & \\
\hline 3 & $\begin{array}{c}17.32 \\
\mathrm{~N} / \mathrm{mm} 2 \\
\end{array}$ & \\
\hline b) 28 days & & $\begin{array}{c}\text { Equal or Greater than } 42.5 \\
\mathrm{~N} / \mathrm{mm} 2\end{array}$ \\
\hline 1 & $\begin{array}{c}45.6 \\
\mathrm{~N} / \mathrm{mm}^{2}\end{array}$ & \\
\hline 2 & $\begin{array}{c}44.1 \\
\mathrm{~N} / \mathrm{mm}^{2} \\
\end{array}$ & \\
\hline 3 & $\begin{array}{c}46.2 \\
\mathrm{~N} / \mathrm{mm}^{2} \\
\end{array}$ & \\
\hline
\end{tabular}

preparing 12 cubes for each sample. The fresh concrete mixes were casted in standard test moulds of $150 \mathrm{~mm}$ cubic -according to BS1881: sections 108 and 116 (Also SABS standard method 863), whereas a standard slump cone of $300 \mathrm{~mm}$ high, $150 \mathrm{~mm}$ diameter cylinder according to ASTM standard was used for measuring concrete slumps. The concrete mix design sheet is attached in appendix (B). The results of these experiments are shown in the following tables and figures.

\subsection{Preliminary Tests Results of Cement}

The particle size distribution of aggregates is called grading. Grading determines the paste requirement for a workable concrete since the amount of voids among aggregate particles requires the same amount of cement paste to fill out in the concrete mixture. To obtain a grading curve for an aggregate, sieve analysis has to be conducted. The commonly used sieve designation is listed in Table ((2) and (3) (. 


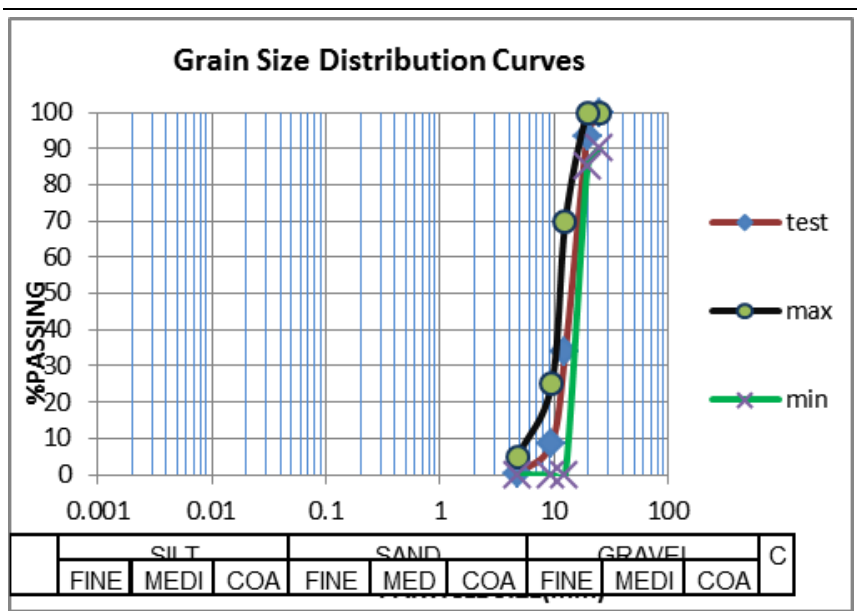

Fig(1): Grain Size of Coarse Aggregate Test

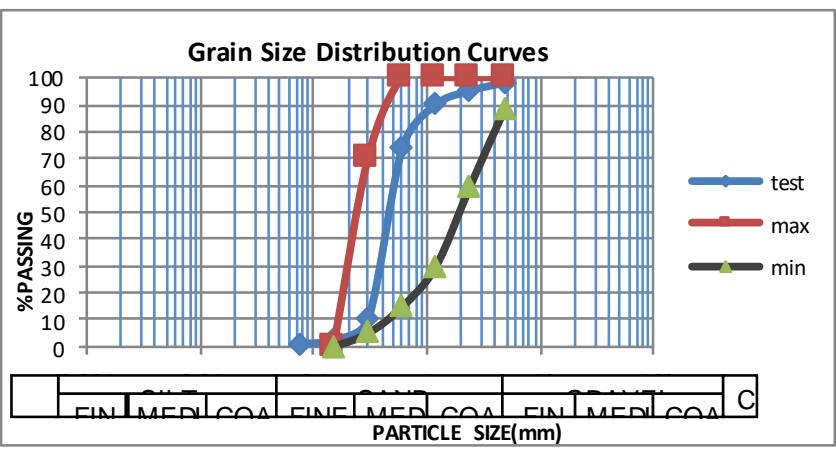

Fig(2) Grain Size of Fine Aggregate Test

Table (4): Silt content in fine aggregate

\begin{tabular}{c|c|c}
\hline \hline Sample No. & 1 & 2 \\
\hline $\begin{array}{c}\text { Sample Total } \\
\text { Weight }(\mathrm{g})\end{array}$ & 1000 & 1000 \\
\hline $\begin{array}{c}\text { Weight }(\mathrm{g}) \\
\text { After Washing }\end{array}$ & 992 & 991 \\
\hline Silt andclay(\%) & 0.8 & 0.9 \\
\hline \hline
\end{tabular}

Table (5): Results of Slump test improved by Superplasticizer ratios

\begin{tabular}{c|l|l|l|l|l}
\hline \multicolumn{7}{c}{ and water reduction } \\
\hline $\begin{array}{c}\text { Superplasticizer } \\
\text { (Litre/50kg } \\
\text { cement) }\end{array}$ & 0.0 & 0.4 & 0.8 & 1.2 & 1.5 \\
\hline $\begin{array}{c}\text { Water reduction } \\
(\%)\end{array}$ & $0 \%$ & $10 \%$ & $15 \%$ & $20 \%$ & $30 \%$ \\
\hline Slump (mm) & 40 & 90 & 180 & 190 & 185 \\
\hline \hline
\end{tabular}

\subsection{Results of Aggregate Tests}

The particle size distribution of aggregates is called grading. Grading determines the paste requirement for a workable concrete since the amount of voids among aggregate particles requires the same amount of cement paste to fill out in the concrete mixture. To obtain a grading curve for an aggregate, sieve analysis has to be conducted. The commonly used sieve designation is listed in Table ((2) and (3) (.
2.4 Results of workability (Slump) for Fresh Concrete Tests

The equipment for the slump test is indeed very simple. It consists of a tamping rod and a truncated cone, $300 \mathrm{~mm}$ in height, $100 \mathrm{~mm}$ in

Table (3): Results of sieve analysis of fine aggregate test

\begin{tabular}{c|c|c|c|c|c|c|l}
\hline \hline \multirow{2}{*}{$\begin{array}{c}\text { B.S } \\
\text { sieve }\end{array}$} & \multicolumn{5}{|c|}{ Retained } & \multirow{2}{*}{\begin{tabular}{l} 
B \\
\cline { 2 - 6 }
\end{tabular}} & \multicolumn{2}{|c|}{ Sample } & \\
\hline$(\mathrm{mm})$ & Wt. (g) & $(\%)$ & Wt. (g) & $(\%)$ & $(\%)$ & & \\
\hline 4.75 & 0.016 & 1.6 & 0.019 & 1.9 & 1.75 & 98.25 & 89 to 100 \\
\hline 2.36 & .029 & 2.9 & 0.031 & 3.1 & 3 & 95.25 & 60 to 100 \\
\hline 1.18 & .0052 & 5.2 & 0.052 & 5.2 & 5.2 & 90.05 & 30 to 100 \\
\hline 0.600 & .0158 & 15.8 & 0.161 & 16.1 & 15.95 & 74.1 & 15 to 100 \\
\hline 0.300 & .0626 & 62.6 & 0.656 & 65.6 & 64.1 & 10 & 5 to 70 \\
\hline 0.150 & .0096 & 9.6 & 0.062 & 6.2 & 7.9 & 2.1 & 0 to $15 \mathrm{a}$ \\
\hline 0.075 & 0.023 & 2.3 & 0.019 & 1.9 & 2.1 & 0.4 & - \\
\hline pan & & 00 & 00 & 00 & 00 & 00 & 00 \\
\hline \hline
\end{tabular}

diameter at the top, and $200 \mathrm{~mm}$ in diameter at the bottom. To conduct a slump test, first moisten the slump test mold and place it on a flat, nonabsorbent, moist, and rigid surface. Then hold it firmly to the ground by foot supports.

Next, fill $1 / 3$ of the mold with the fresh concrete and rod it 25 times uniformly over the cross section. Likewise fill 2/3 of the mold and rod the layer 25 times, then fill the mold completely and rod it 25 times. If the concrete settles below the top of the mold, add more. Strike off any excessive concrete. Remove the mold immediately in one move. Measure and record the slump as the vertical distance from the top of the mold to average concrete level.

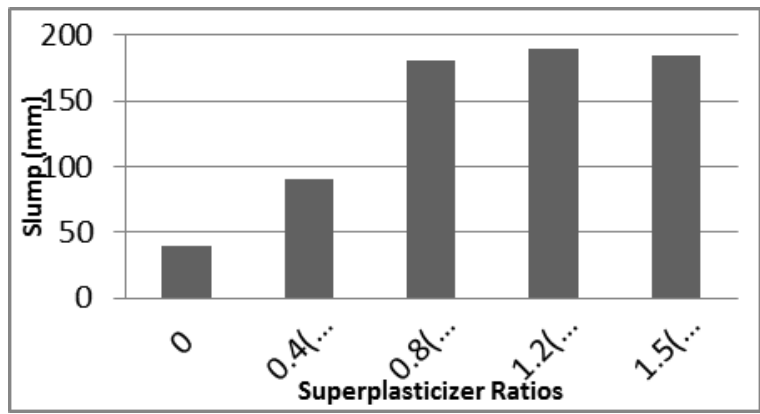

Fig (3): Relationship between Results of Slumps and Superplasticizer ratios and water reduction TABLE (6): RESULTS OF SLUMPS TEST IMPROVED BY

\begin{tabular}{c|c|c|c}
\hline \hline $\begin{array}{c}\text { Superplasticizer } \\
\text { (Littre/50kg } \\
\text { cement) }\end{array}$ & 0.0 & 0.4 & 0.8 \\
\hline $\begin{array}{c}\text { Water reduction } \\
(\%)\end{array}$ & $0 \%$ & $10 \%$ & $15 \%$ \\
\hline $\begin{array}{c}\text { Cement } \\
\text { reduction (\%) }\end{array}$ & $0 \%$ & $10 \%$ & $15 \%$ \\
\hline Slump (mm) & 40 & 50 & 85 \\
\hline \hline
\end{tabular}




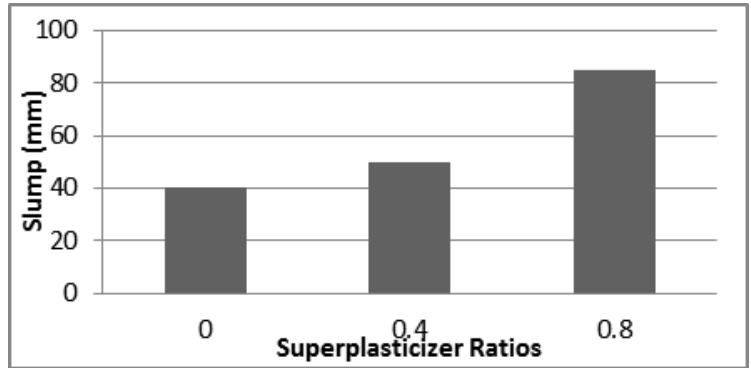

Fig(4): Relationship between Results of Slumps and Superplasticizer ratios and (water \&cement) reduction

\subsection{Results of Concrete Water Absorption Tests}

Compressive Strength Test:

The tests are required to determine the strength of concrete and therefore its suitability for the job. The equipment used in the test is crush machine $(2000 \mathrm{KN})$, curing tank, balance and moulds.

Procedure the Test:

- Representative samples of concrete shall be taken and used for casting cubes $15 \mathrm{~cm} \times 15 \mathrm{~cm}$ $x 15 \mathrm{~cm}$.

- The concrete shall be filled into the moulds in layers approximately $5 \mathrm{~cm}$ deep it would be distributed evenly and compacted either by vibration or by hand tamping. After the top layer has been compacted, the surface of concrete shall be finished level with the top of the mould using a trowel; and covered with a glass plate to prevent evaporation.

- The specimen shall be stored at site for 24 hours under damp matting or sack. After that, the samples shall be stored in clean water until the time test.

- Specimen shall be tested immediately on removal from water and while they are still in wet condition.

- The load shall be applied slowly without shock and increased continuously.[15]

Compressive Strength is calculate using the following formula:

Compressive Strength $(\mathrm{kg} / \mathrm{cm} 2)$

$$
\text { Wf / Ap }
$$

$\mathrm{Wf}=$ Maximum applied load just before load, $(\mathrm{kg})$ Ap $=$ plan area of cube mould, $\left(\mathrm{mm}^{2}\right)$

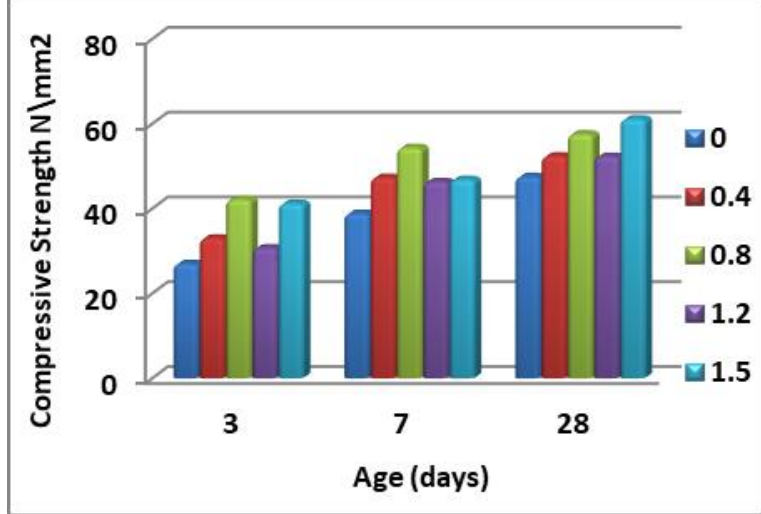

Fig (5): Compressive strength developed for concrete mixes using superplasticizer ratios of (0.4 - 0.8 - $1.2-1.5) \mathrm{L}$ per $50 \mathrm{~kg}$ cement and $(10 \%, 15 \%, 20 \%$ and $30 \%)$ water reduction.

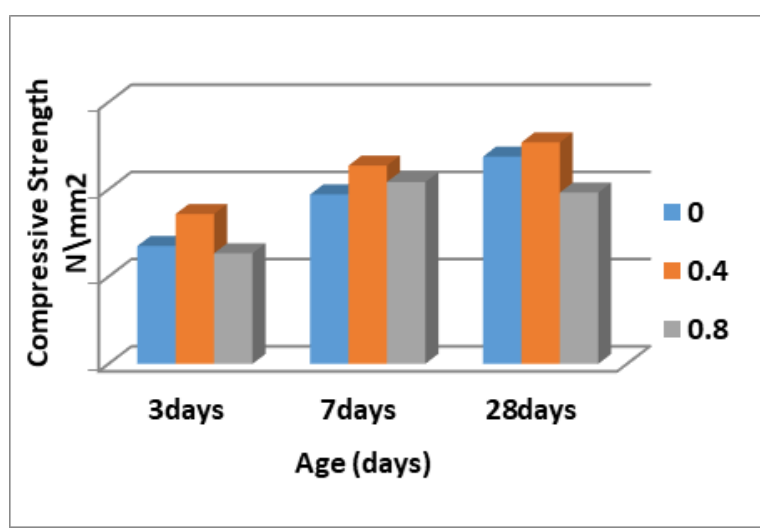

Fig(6): Compressive strength of concrete mixes developed by using Super plasticizer ratios of $(0.0,0.4$ and 0.8$)$ Litre per $50 \mathrm{~kg}$ of cement, water reduction of $(10 \%$ and $15 \%)$ and cement reduction of $(10 \%$ and $15 \%)$.

\section{DISCUSSIONS OF THE PRELIMINARY RESULTS OF CONCRETE CONSTITUENTS:}

Laboratory tests were carried out to ensure that the main constituents of concrete (cement \& aggregates), are adequate and conforming with the requirements of the (BS) standards code (British standards). The results of these preliminary experiments shown that the cement used in this research comply with BS 121996 as shown in Table (1). Results of coarse aggregate and fine aggregate are presented in Tables (2) and (3) respectively. From Table (2) and Fig.(1) it is noticed that the grading of coarse aggregate satisfied the BS 812-103.1 (882:1992), whereas Table (3) and Fig.(2) indicate that the fine aggregate grading satisfied the BS 812-103 and 882:1992.

\subsection{Workability:}

The slump test was used as a measure of consistency when admixtures were used with ordinary reference mix having $\mathrm{w} / \mathrm{c}$ ratio $(0.48)$. Slumps of ordinary reference mix $40 \mathrm{~mm}$, Slumps 
of mixes containing $(0.4,0.8,1.2 \& 1.5) \mathrm{L}$ superplasticizer per $50 \mathrm{~kg}$ cement and reduced water by $(10 \%, 15 \%, 20 \%, 30 \%)$ respectively are 90 $\mathrm{mm}, 180 \mathrm{~mm}, 190 \mathrm{~mm}$, and $185 \mathrm{~mm}$ respectively. Reduction in the slump in the proportion of 1.5 as a result of a significant reduction in the proportion of $\mathrm{w} \backslash \mathrm{c}$ compared with other ratios presented in Table (5) and Fig (3). Slumps of mixes containing ( $0.4 \mathrm{~L} \& 0.8 \mathrm{~L}$ superplasticizer per $50 \mathrm{~kg}$ cement) reduced water by $(10 \%, 15 \%)$ and reduced cement by $(10 \%, 15 \%)$ respectively are (50mm \& $85 \mathrm{~mm})$ respectively presented in Table (6) and Fig (4). The observed workability of mix containing admixtures was much higher than that of the ordinary reference mix but the workability of reduced cement and water mix containing admixtures was low than that of the mix containing admixtures.

\subsection{Compressive Strength:}

The experimental results the three days compressive strength increases with increasing the dosage of superplasticizer. Addition of $0.4 \%$ superplasticizer increase the three days compressive strength from $27.03 \mathrm{~N} / \mathrm{mm} 2$ to 33.02 $\mathrm{N} / \mathrm{mm} 2(22 \%)$ from the reference concrete, but further increase of superplasticizer from $0.4 \%$ to $0.8 \%$ superplasticizer increase the three days compressive strength only from $27.03 \mathrm{~N} / \mathrm{mm} 2$ to $42.17 \mathrm{~N} / \mathrm{mm} 2(56 \%)$. increase of superplasticizer from $0.8 \mathrm{~L}$ to $1.2 \mathrm{~L}$ increase the three days compressive strength only from $27.03 \mathrm{~N} / \mathrm{mm} 2$ to $30.73 \mathrm{~N} / \mathrm{mm} 2(14 \%)$ but when the ratio of superplasticizer increased from $1.2 \mathrm{~L}$ to $1.5 \mathrm{~L}$ the three days compressive strength increased from $27.03 \mathrm{~N} / \mathrm{mm} 2$ to $41.21 \mathrm{~N} / \mathrm{mm} 2$ by an amount of $52 \%$. This fact is also true for ages 7 days and 28 days compressive strength which increased significantly as superplasticizer ratios increased. For 7 days, the increasing rate of the compressive strength ranging from $19 \%$ to $35 \%$ with respect to control mix and ratios of additive, while for 28 days the increasing rate ranging from $10 \%$ to $29 \%$. The experimental results the addition of $0.4 \mathrm{~L}$ increased the 28 days compressive strength from $47.53 \mathrm{~N} / \mathrm{mm} 2$ to $50.78 \mathrm{~N} / \mathrm{mm} 2(7 \%)$ and the addition of $0.8 \mathrm{~L}$ decrease the 28 days compressive strength from $47.78 \mathrm{~N} / \mathrm{mm} 2$ to $39.28 \mathrm{~N} / \mathrm{mm} 2$ (17 $\%)$ The experimental results shown in Fig (5). The decreasing in strength is thought to be due to reduction in cement contents It has been shown from Fig (6) that addition of super plasticizer to great extent with the reduction of cement and water leads to reduce strength as in case of $0.8 \mathrm{~L}$ and the best results were achieved when adding $0.4 \mathrm{~L}$.

\subsection{Absorption:}

The values of absorption are fluctuating irrespective to ratios of superplasticizer or rates of water reductions. the values of absorption decreased with increasing superplasticizer ratios $(0.4 \%$ and $0.8 \%)$ and increasing the reduction of water and cement content.

\section{CONCLUSIONS}

This research was conducted to study the effect of superplasticizer (SP) on the properties of fresh and hardened concrete.

The properties investigated were workability (slump), and compressive strength. From the results of this research it can be concluded that:

1- The significant effect of superplasticizer on the properties of fresh concrete occurred in all ratios of this additive when adding to concrete mixes.

2- It is observed that slumps of mixes containing ratios of SP with reduction of water content varied between $90 \mathrm{~mm}$ to $190 \mathrm{~mm}$, i.e., much higher than that of the ordinary reference mix ( slump $=40 \mathrm{~mm}$ ) and nearly more than double that of mixes containing SP with reduction of water and cement (slumps reached up to $85 \mathrm{~mm}$ ). However, very high dosages of SP tend to impair the cohesiveness of concrete.

3-It is noticed that all ratios of SP added to concrete mixes increased the compressive strengths much more than that of normal concrete mix.

4 -It is found that $0.4 \mathrm{~L}$ of SP with (water and cement) reduction resulted in the best compressive strength, whereas $0.8 \mathrm{~L}$ of SP with (water) reduction resulted in the highest compressive strength of concrete mixes.

5- It is observed that the values of absorption showed no steady state of changes with respected to the used ratios of SP or w/c contents. 


\section{REFERENCES}

1- Neville A.M. and J. J. Brooks, "Concrete Technology". 2010; Second edition.

2- Shetty M.S. Concrete Technology Theory and Practice. 2005;sixth edition.

3- Paul Lohtia and Ramesh C.Joshi. ,"Concrete Admixtures Hand Book"2nd Edition Noys Publisher, 1995

4- Robberts JM. Reinforced concrete structures. 2004

5- Malhotra V. M, Results of a laboratory Study Superplasticizers in Concrete. 1978

6- Saeed Ahmad* M.N., AyubElahi,Effectof Superplasticizers on Workabilityand Strengthof Concrete. 30th Conference on our World in Concrete \& Structures 2005.

7- Mbadike E. Effect of Superplasticizer on the Compressive Strength of Concrete.International Journal of Natural and Applied Sciences. 2011; volume 7,NO1:37 - 40.

8- Alsadey S. Effects of Superplasticizing Admixture on Properties of Concrete.International Conference on Transport, Environment and Civil Engineering (ICTECE'2012). 2012:132-4.

9- Alsadey S. Effects of Super Plasticizing and Retarding Admixtures on Properties of Concrete. International Conference on Innovations in Engineering and Technology(ICIET'2013). 2013:271-4.

10- Gayathri Devi M EJ. Effect of Re-Dosing Superplasticizer to Regain Slump onConcrete. International Journal of Innovative Research in Advanced Engineering (IJIRAE). 2014;Volume 1(Issue 8):139-43.

11- Dumne SM. Effect of Superplasticizer on Fresh and Hardened Properties of Self-Compacting Concrete Containing Fly Ash. American Journal of Engineering Research(AJER). 2014; Volume-03, (Issue-03):pp-205-11.R.

12- Salahaldein Alsadey, "Effect of Superplasticizer on Fresh and Hardened Properties of Concrete ", Journal of Agricultural Science and Engineering Vol. 1, No. 2, 2015, pp. 70-74 http://www.publicscienceframework.org/journal/jase.

13- Evangeline.K, Dr. M.Neelamegam, " Effect of Superplasticizer on Workability and Mechanical Properties of Self-Compacting Concrete", IOSR Journal of Mechanical and Civil Engineering (IOSR-JMCE) e-ISSN: 2278-1684, p-ISSN: 2320-334X. PP 18-29 www.iosrjournals.org. Neville A.M. and J. J. Brooks, "Concrete Technology". 2010; Second edition.

14- Malhotr V.M., " Advantages Concrete Technology " Second Edition

15- Zongjin Li. Advanced Concrete Technology. 2011 